\begin{tabular}{ll}
\hline \hline MINING AND METALLURGY INSTITUTE BOR & ISSN: 2334-8836 (Štampano izdanje) \\
UDK: 622 & ISSN: 2406-1395 (Online) \\
\hline
\end{tabular}

\title{
PRESSURE CONDITION AROUND THE UNDERGROUND OPENING SUBSTRUCTURED BY ANCHORS IN MULTILAYERED DEPOSITS INVESTIGATED BY THE METHOD OF FINAL ELEMENTS
}

\begin{abstract}
Computer program ADINA is used for pressure analysis on a model of underground opening, semi-circular in shape, where there are the layers of lignite, and conducted pressure analysis, before, during and after the setting of three and five anchors. Theory on pressure distribution for secondary and tertiary pressure condition in the roof and board sides of the opening by setting anchors has been proven. In order to check the result, test of removing anchors from the roof and board sides of the opening was done. Testing and research, conducted at the level of obtained results, show the efficiency of setting underground opening using the anchors where there are multilayered deposits of lignite. The research results, provided in this paper, can be also used for other underground openings containing multilayered deposits.
\end{abstract}

Keywords: pressure conditions, multilayered deposits, substructure, anchor, ADINA

\section{INTRODUCTION}

In the process of substructure, it is necessary to make an assessment of substructures which include the adequate choice of rock mass classification, but also the other technical conditions that have to be explored in order to make a good project. In the applied rock mechanics, in the field of mining, planning includes the choice of specific objects and provides the investigation of rock mass behavior in modified condition using the equations of theoretical and applied rock mechanics. Analysis the primary pressure condition by numerical methods, and also analysis the secondary and tertiary pressure condition by the method of final elements, using the program package ADINA in conditions before, during and after the setting of anchors in the underground openings for multilayered deposits, give the useful, effi cient and legitimate solutions. The primary research goal of this paper is a numerical justification of legitimacy and efficiency of the applied system model of setting the underground openings using the anchors where there are multilayered deposits in mining conditions of the lignite deposit Kreka. (3)

\section{KREKA COAL BASIN}

The coal basin Kreka is a part of the Tuzla tertiary basin, situated in the southwestern part of the town, between the southern slopes of the mountain Majevica and valley of the river Spreča (Figure 1), covering an area of $180 \mathrm{~km}^{2}$. The whole basin is located in Tuzla Canton, and spreads to the areas of the municipalities Tuzla, Lukavac, Kalesija and Živinice.

\footnotetext{
* BCC Tuzla Canton, Tuzla
} 


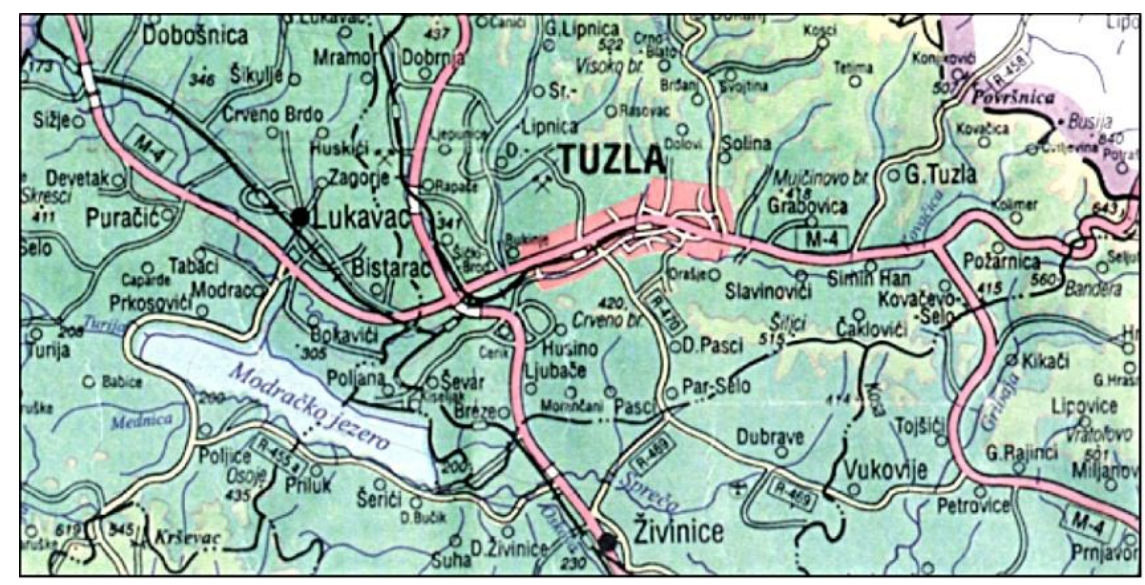

Figure 1 Spatial position of the Kreka coal basin

Five lignite layers were developed in this part of the basin of different economic significance and their development is shown in the geological - stratigraphic column, which completely coincides with lithostratographic development of overall Kreka basin in general. Coal layers are continuosly developed in the whole deposit, with the exception of roof layers in the Kovačevići syncline. Thickness of coal layers, including intercalations, varies in wide ranges (from 5 to $34 \mathrm{~m}$ ). However, the coal layers almost never lose their productive thickness and quality.

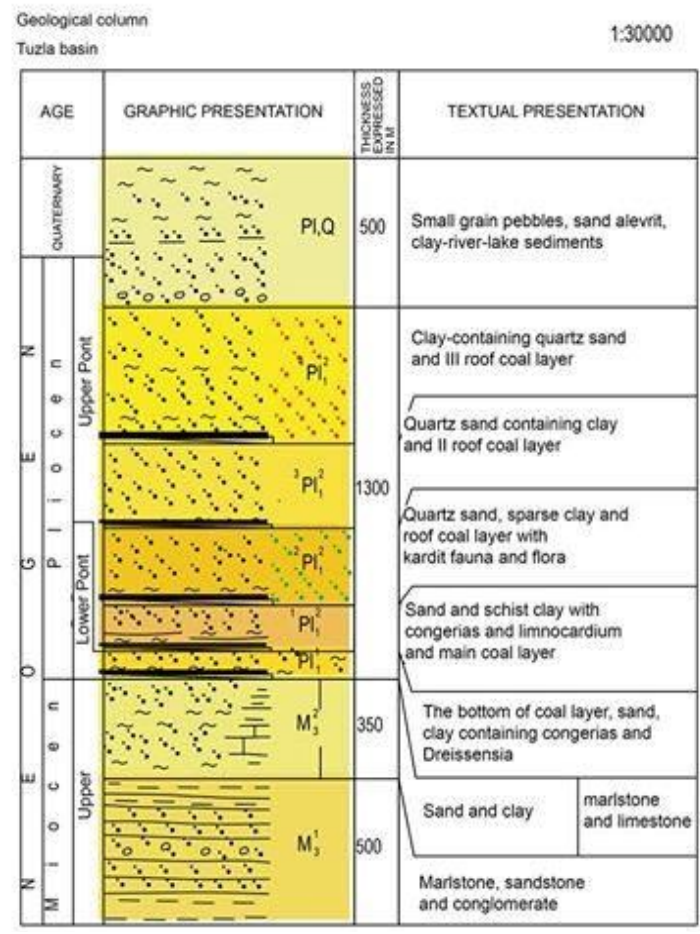

Figure 2 Geological-stratigraphic column of the Kreka synclinorium 


\section{ANALYSIS OF PRESSURE \\ CONDITION AROUND UNDER- GROUND OPENING IN A COAL LAYER BY THE METHOD OF FINAL ELEMENTS}

\section{Program package ADINA}

ADINA (Automatic Dynamic Incremental Nonlinear Analysis) is a commercial finite element analysis program package which has widespread usage in the industry and academic community, since it is suitable for the analysis of pressure in solid rocks (2D and 3D models) of different structures. In this paper, 8.6 version is used, and it shows a difference in pressure rearrangement between the unsubstructured opening and substructured opening by anchors, i.e. it shows the secondary and tertiary pressure condition in the roof and board sides of the opening, which is the result of anchor setting. (1)

\section{Input parameters of the work environment}

Input parameters of the work environment include geomechanical characteristics of the work environment, lithological structure in the area of analyzed case, geometry of underground opening, unsubstructured or substructured by anchors.

Table 1 Geomechanical characteristics

\begin{tabular}{|l|l|l|l|l|}
\hline $\begin{array}{c}\text { TOP OF CLAY } \\
\text { LAYER }\end{array}$ & \multicolumn{1}{|c|}{$\begin{array}{c}\text { COAL } \\
\text { LAYER I }\end{array}$} & $\begin{array}{c}\text { COAL } \\
\text { LAYER II }\end{array}$ & $\begin{array}{c}\text { COAL } \\
\text { LAYER III }\end{array}$ & $\begin{array}{c}\text { BOTTOM OF } \\
\text { CLAY LAYER }\end{array}$ \\
\hline$\gamma=21 \mathrm{kN} / \mathrm{m}^{3}$ & $\gamma=12 \mathrm{kN} / \mathrm{m}^{3}$ & $\gamma=12 \mathrm{kN} / \mathrm{m}^{3}$ & $\Gamma=13 \mathrm{kN} / \mathrm{m}^{3}$ & $\gamma=1.70 \mathrm{kN} / \mathrm{m}^{3}$ \\
\hline$v=0.40$ & $v=0.21$ & $v=0.22$ & $Y=0.22$ & $v=0.35$ \\
\hline $\mathrm{C}=0.07 \mathrm{MPa}$ & $\mathrm{C}=3.5 \mathrm{Mpa}$ & $\mathrm{C}=3.2 \mathrm{MPa}$ & $\mathrm{C}=3.0 \mathrm{MPa}$ & $\mathrm{C}=30 \mathrm{MPa}$ \\
\hline$\varphi=22^{\circ}$ & $\varphi=30^{\circ}$ & $\varphi=30^{\circ}$ & $\Phi=30^{\circ}$ & $\varphi=35^{\circ}$ \\
\hline$\sigma_{\mathrm{z}}=0.02 \mathrm{MPa}$ & $\sigma_{\mathrm{z}}=1.4 \mathrm{Mpa}$ & $\sigma_{\mathrm{z}}=1.3 \mathrm{MPa}$ & $\sigma_{\mathrm{z}}=1.20 \mathrm{MPa}$ & $\sigma_{\mathrm{z}}=0 \mathrm{MPa}$ \\
\hline $\mathrm{E}=25 \mathrm{MPa}$ & $\mathrm{E}=600 \mathrm{Mpa}$ & $\mathrm{E}=600 \mathrm{MPa}$ & $\mathrm{E}=600 \mathrm{MPa}$ & $\mathrm{E}=300 \mathrm{MPa}$ \\
\hline
\end{tabular}

Figure 3 gives a structure profile of coal layer, including the position, type and shape of underground opening which is in the focus of this research and substructure. There are also all necessary and available geomechanical characteristics of coal layer and accompanied deposits for the mining district Marići for the $16^{\text {th }}$ floor (GDVH). These data are used in the paper as the base for all modeling. (2) 


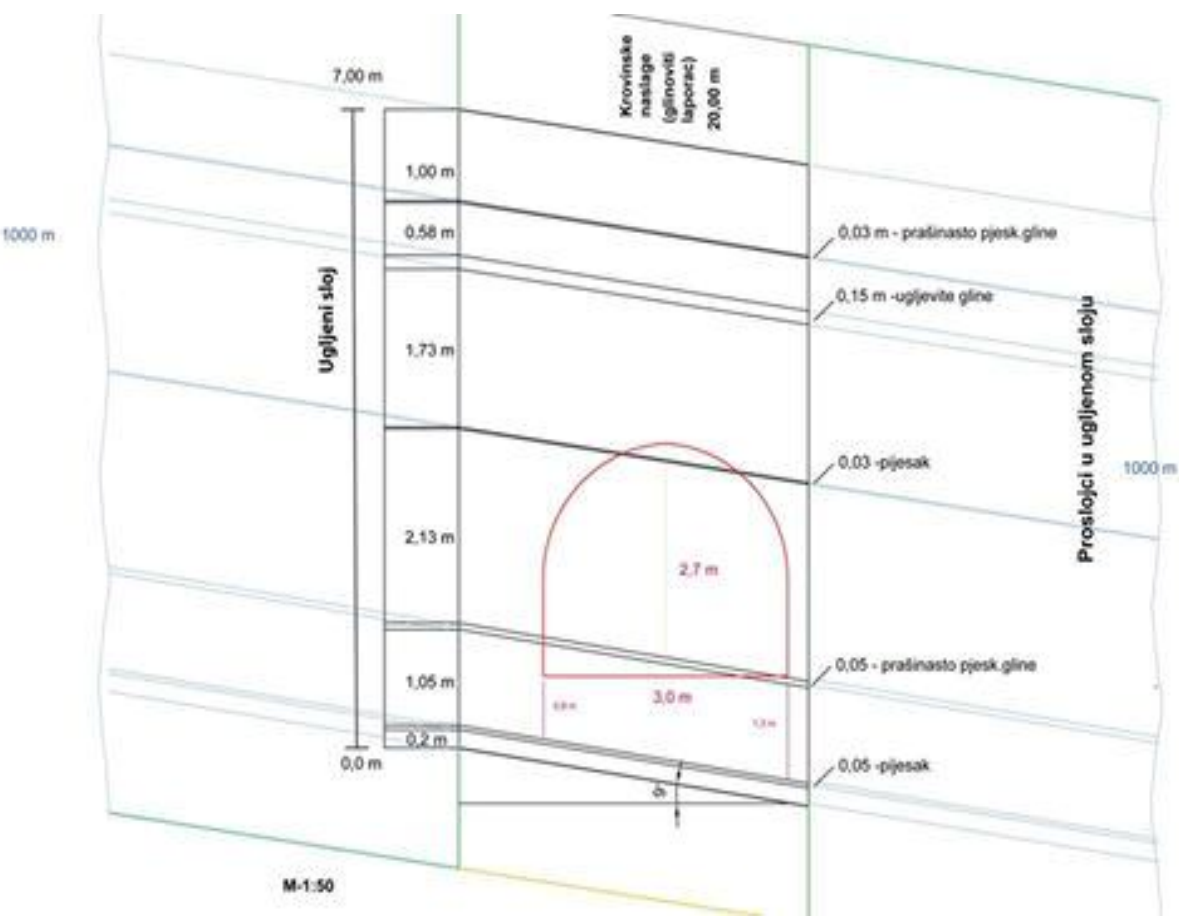

Figure 3 Structure profile for the semi-circular shape of opening for (GDVH-16 $6^{\text {th }}$ floor)

\section{CASE 1:}

The analysis was conducted on two geologic cases. The first case is for substructure of opening by 3 anchors, and the second by 5 anchors.
MKE model with the modified board side conditions and given load with three built-in anchors.
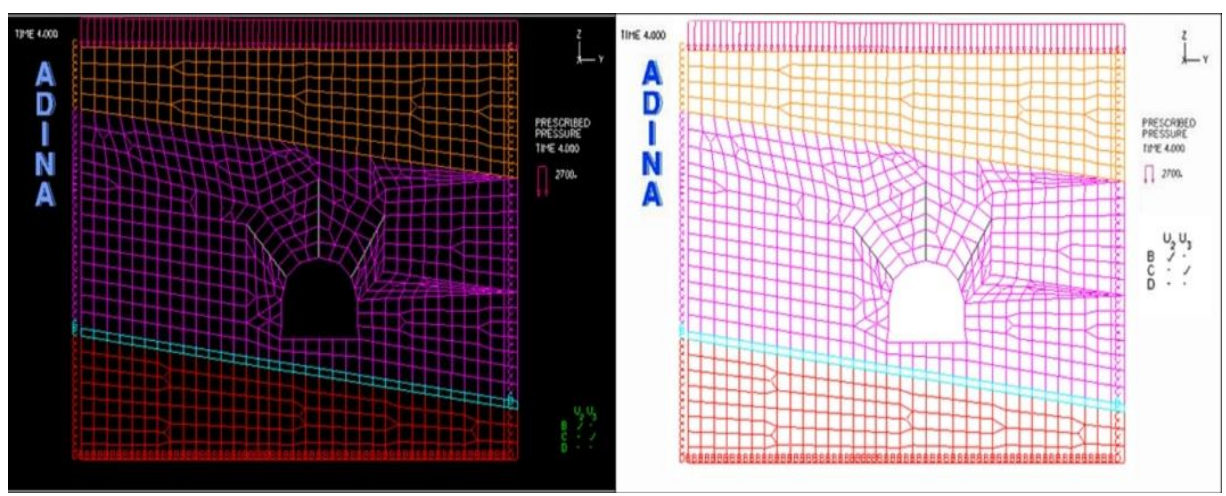


\section{CASE 2:}

MKE model with the specified board side conditions and given load with

five built-in anchors.

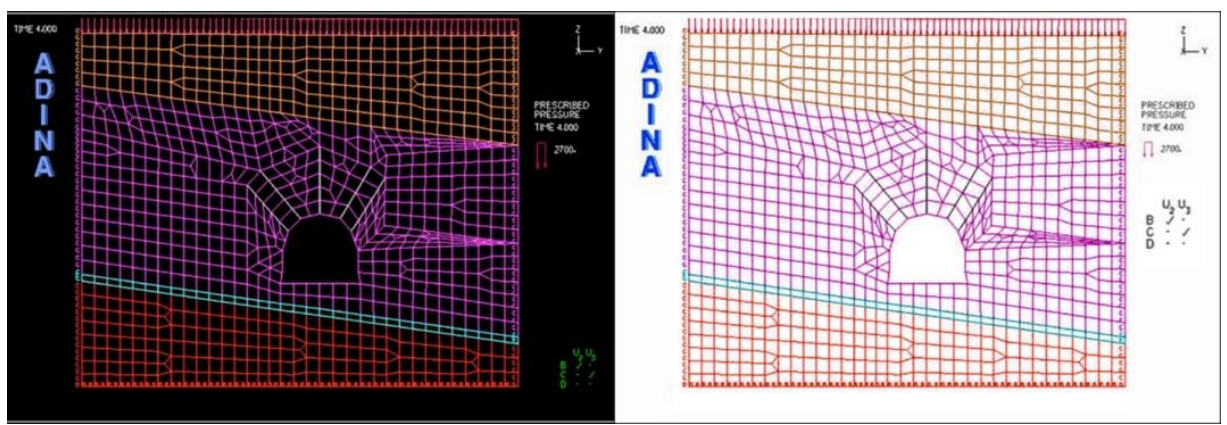

Figure shows in the first case the model of final elements for opening with semicircular roof, built-in anchors, and the position of lithological members and overview the board side conditions. The model contains 3207 nodes, with five groups of elements, and anchors of 14 generalized line (truss) elements, while 2D elements which present coal, roof and material has 1044 quadrilateral elements with 8 Gauss integration points. In the second case, the model contains 3207 nodes with five groups of elements, and anchors of 24 generalized line (truss) elements of coal, roof and material, has 1044 quadrilateral elements with 8 Gauss integration points.

\section{View of vertical pressure $\sigma z$ and axial forces in anchors}

The condition of vertical pressure that is the range of intervals from minimum to maximum value of pressure is given in Figure 4 and expressed in $\mathrm{kN} / \mathrm{m}^{2}$. Negative sign means pressure (-), while plus sign $(+)$ means tensioning.

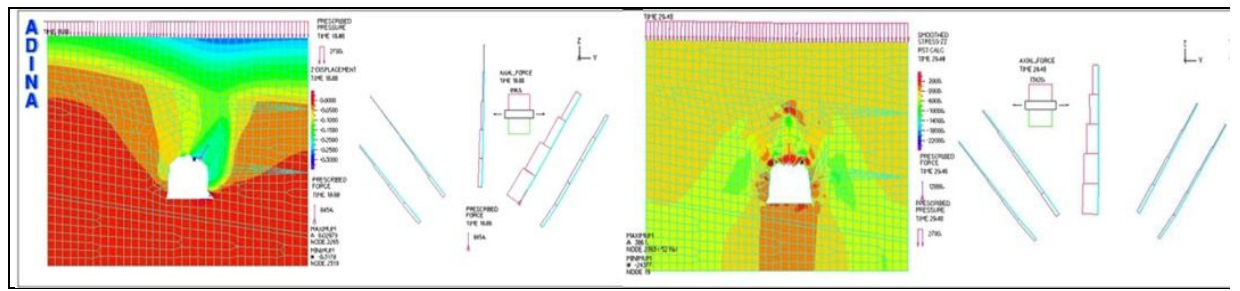

Figure 4 Overview of pressure $\sigma_{z}$ and axial forces in anchors after the excavation of profiles with 3 and 5 anchors

Overview of vertical pressure around the opening highlights the pressure rearrangement in massif. The load in anchors suggests that the middle anchor has less force intensity, while board side anchors take higher load, and the expressed asymmetry is the consequence of position of layers. Also, a detailed overview of axial load affecting anchors is given. In the overview, the pressure is expressed on the upper side, while the bracing is given on the lower side and expressed in $\mathrm{kN}$. In the case of 5 anchors, unlike the case where 3 anchors were set in opening, it can be noticed that the pressure 
load intensity is lower (by absolute value), but also that bracing load intensity is higher in the bottom part of opening. The load intensity in anchors is also higher.

\section{Plastic deformations, vertical shift, plastic flag}

The extent of plastic deformations is of less intensity around opening with built-in anchors. Plastic deformations are especially noticeable in the bottom right corner of opening, which is the consequence of litho logical composition and the shape of opening (there is sand in the bottom part), and also because the sharp corners cause high concentration of pressure. Plastic deformations are expressed in percentages $(\%)$. The extent of plastic deformations for opening without anchors is higher than for opening with anchors. It is also noticeable that the intensity of plastic deformations, in this case, is lower with 5 built-in anchors, than in the case of the same opening with 3 built-in anchors.

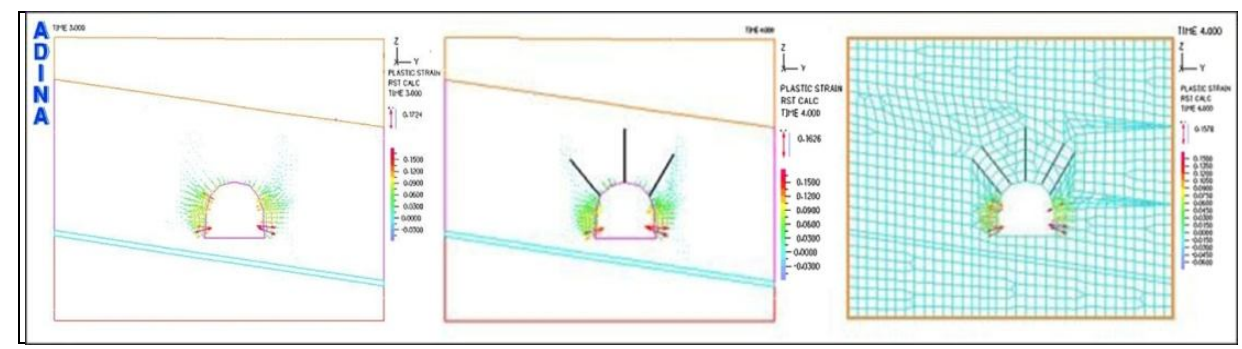

Figure 5 Comparative overview of plastic deformations before and after mounting of 3 and 5 anchors

Vertical shifts give an illustrative example when the usage of anchors is in case, since mounting of anchors in the short time after constructing the opening has a significant effect on height reduction of opening. It is noticeable from illustration that there is a change of scope of excavation to the secondary pressure condition in the massif, and the changes of se- condary pressure conditions in the massif after mounting of anchors. The lines of vertical shift indicate that there is a significant change in rearrangement of vertical shifts with 5 built-in anchors. By comparison for the same conditions but for opening with only 3 built-in anchors, it is noticeable that the intensity of vertical shifts is lower.

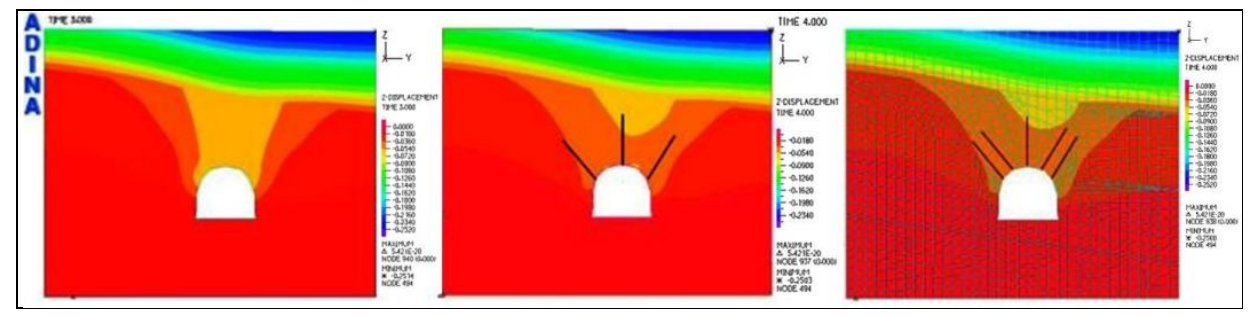

Figure 6 Comparative overview of vertical shifts before and after mounting of 3 and 5 anchors

Plastic flag is the indicator of emergence of plastic deformation in the Gauss points of elements. It indicates the zones and elements affected by plastic deformation. It is noticeable from the legend that plastification occurred as the conse 
quence of overflow the Mohr-Coulomb fracture condition. This zone is significantly more acute without anchors. Plastification for other conditions and criteria (pressure and bracing firmness) was not found. Also, the legend explains on which models the plastic deformation can or has to be expressed due to bracing or overflow the Mohr-Coulomb fracture condition and it also shows that there is an evident difference between the case with 3 and the case with 5 anchors.

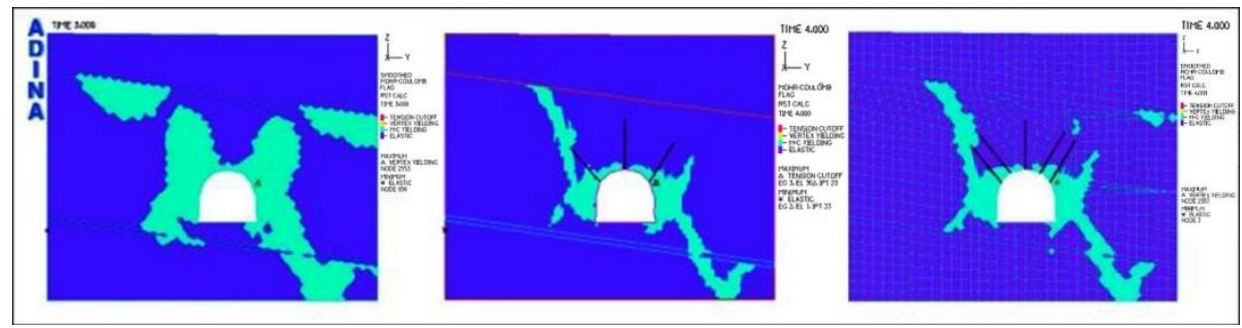

Figure 7 Comparative overview of plastic flag during the period before and after mounting of 3 and 5 anchors

\section{Pull-out force}

The results of pull-out force of anchors are considered and offered on the same model, but only from different positions of built-in anchor in a roof vertically, or in a board side of opening. The results consider the vertical shift and overview the force intensity. First, the pull-out force of the board side anchor was modeled, and then the pull-out force of the anchor set in a roof. The size of the forces and shifts is present and given in appropriate drawings and it is evident is that the pull-out force is higher in the case of set anchors in a roof.

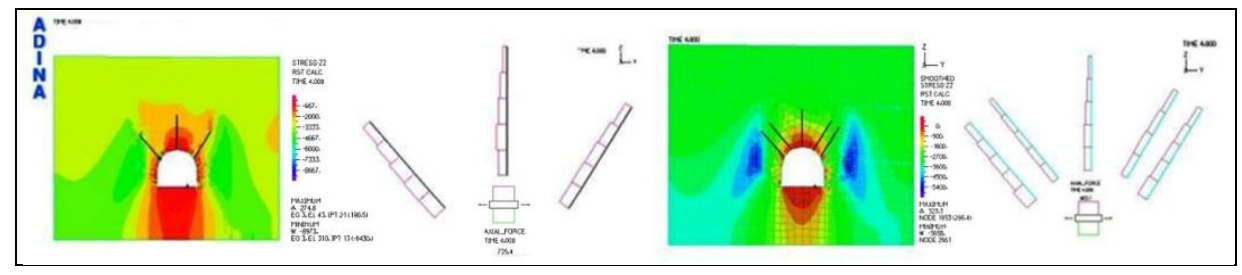

Figure 8 Pull-out force of anchor set in a roof

\section{CONCLUSION}

Based on the obtained results, it can be concluded that in the Mramor lignite mine, based on the analyzed profile of semicircular roof of opening on the $16^{\text {th }}$ floor (TOH-16), there is an evident difference in pressure rearrangement in case of substruc ture using three anchors and substructure using five anchors. Since the analysis of pressure condition around the underground openings is a safe method for the choice of substructuring underground openings by anchors, the pressure analysis was conduc- 
ted by numerical methods using the licensed software ADINA, version 8.6 at the Faculty of Mining, Geology and Civil Engineering. Model ADINA in engineering terms gives reliable results offering reliable perspective on pressure and force of anchors. Through software analysis of pressure, the thesis on pressure rearrangement for the secondary and tertiary pressure condition in the roof and board sides of the opening by setting anchors was proved, which is supported by the obtained results. The pull-out force obtained from the modeled value has to be considerably lower than the force of practical pull-out, because in this case the support is formed with the support of pump and temporarily built-in support, which gives higher value of pull-out force than modeled force.

\section{REFERENCES}

[1] ADINA, R\&D, Inc., Theory and Modeling Guide, Volume I: ADINA, Watertown, USA, 2000;

[2] Filipović Z., Elaborate on Classification, Categorization and Calculation of Coal Reserves of the Main and Underlaying Seam to the Elevation $+50 \mathrm{~m}$ in the Area Mramor - North Kreka Displacement, 2001;

[3] Fejzić, S., Stress Analysis of Supporting the Underground Rooms in the Layered Deposits by Anchoring,
Doctoral Dissertation, Faculty of Mining Prijedor, University of Banja Luka, Prijedor, 2014;

[4] Gutić, K., Avdić M., Fejzić, S., Muratović, M., Omega Anchor in the System of Combined Supporting, The Second International Scientific Symposium GTZ 2012 Tuzla, Tuzla, 2012;

[5] Osmić M., Gutić, K., Mandžić, K., Brkić, J., Fazlić, E., Fejzić, S., The Use of Anchors in Solving the Passage of Broad Face through the Rooms Developed in the Excavation Front, University of Tuzla, Tuzla RGGF, Proceedings RGGF Tuzla, No. XXXVI, Tuzla, 2012;

[6] Additional Mining Project, Coal Mine Kreka in Tuzla, Opening and Preparation the I Horizontal Mining District of the Marici Pit of the Main Layer of the Mine Mramor in Mramor, Documentation of the mine Kreka, Tuzla, 2004;

[7] Additional Mining Project, Mines Kreka in Tuzla, Mine Mramor in Mramor, Mining of 60m'-KMŠC II and Other Belts of the Mining District of Mramor Pit, Main Layer of the Mine Mramor in Mramor with an Extension of up to $15 \mathrm{~m}$ in the Blind Part, Diassembly, Relocation and Assembly, Documentation of the Mine Mramor, Mramor 2009. 


\begin{tabular}{ll}
\hline \hline INSTITUT ZA RUDARSTVO I METALURGIJU BOR & ISSN: 2334-8836 (Štampano izdanje) \\
UDK: 622 & ISSN: 2406-1395 (Online) \\
\hline \hline
\end{tabular}

Semir Fejzić*

\section{STANJE NAPONA OKO PODZEMNE PROSTORIJE PODGRAĐENE ANKERIMA U SLOJEVITIM LEŽIŠTIMA ISTRAŽENO METODOM KONAČNIH ELEMENATA}

Izvod

Kompjuterski program ADINA korišten je za naponsku analizu na modelu podzemene prostorije polukružnog oblika u sloju lignita, urađenom naponskom analizom prije, za vrijeme, i poslije ugradnje tri i pet ankera. Dokazana je teza o preraspodjeli napona za sekundarno i tercijarno naponsko stanje u svodu i bokovima prostorije ugradnjom ankera. Za provjeru rezultatai urađen je test čupanja ankera iz stropa i boka prostorije. Provedena ispitivanja i istraživanja na ovom stepenu dosegnutih rezultata pokazuju efikasnost podgrađivanja podzemnih prostorija korištenjem ankera u uslovima slojevitih ležišta lignita. Rezultati istraživanja, dati u ovom radu, mogu biti primjenjivi $i$ za druge podzemne građevine u uslovima slojevitih ležišta.

Ključne rïječi: naponska stanja, slojevita ležišta, podgrađivanje, anker, ADINA

\section{UVOD}

Prilikom podgrađivanja potreban pristup za procjenu podgrade uključuje adekvatan odabir klasifikacije stijenskih masa, kao i drugih tehničkih uslova koji se moraju istražiti kako bi se napravio dobar projekat vezan za izbor podgrade. U primijenjenoj mehanici stijena, na područja rudarstva, projektovanje uključuje izbor određenih objekata i predviđa izučavanje ponašanja stijene $\mathrm{u}$ promijenjenim uslovima sekundarnog stanja napona, koristeći pri tome i jednačine teorijske i primijenjene mehanike stijena. Numeričkim metodama analizano primarno stanje napona, i analiza sekundarnog i tercijarnog naponskog stanja, metodom konačnih elemenata, koristeći programski paket ADINA u uslovima prije, za vrijeme i poslije ugradnje ankera $u$ podzemnoj prostoriji, za slojevita ležišta, daju korisna, efikasna i opravdana rješenja. Primarni cilj istraživanja ovog rada je numerička potvrda opravdanosti i efikasnosti kod primjenjivog modela sistema podgrađivanja podzemnih prostorija, korištenjem ankera kod slojevitih ležišta u rudarskim uslovima krekanskog lignitnog ležišta. (3)

\section{KREKANSKI UGLJENI BASEN}

Krekanski ugljeni basen predstavlja jedan dio tuzlanskog tercijarnog basena, smješten u njegovim jugozapadnim dijelovima, između južnih padina planine Majevice i doline rijeke Spreče (slika 1.), na površini od oko $180 \mathrm{~km}^{2}$.

Kompletan basen se nalazi u tuzlanskom kantonu, i zahvata dijelove općina: Tuzla, Lukavac, Kalesija i Živinice.

* BKC TK Tuzla 


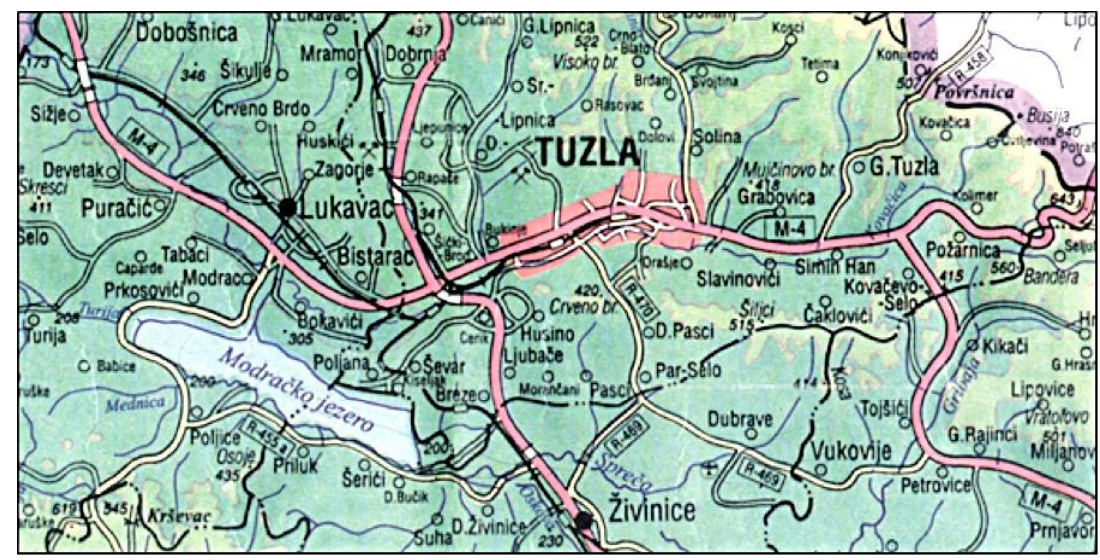

Sl. 1. Prostorni položaj krekanskog ugljenog basena

$\mathrm{Na}$ ovom dijelu basena razvijeno je pet lignitskih slojeva, različitog ekonomskog značaja, a njihov razvoj je dat na geološko -stratigrafskom stubu, koji se u potpunosti podudara sa opštim litostratigrafskim razvojem krekanskog basena u cjelini. Ugljeni slojevi su kontinuirano razvijeni na cijelom ležištu, izuzev krovnih slojeva u sinklinali „Kovačevići“. Debljina ugljenih slojeva, računajući i sve interkalacije, varira u dosta širokim granicama (od 5 do $34 \mathrm{~m}$ ), ali ugljeni slojevi skoro nikada ne gube svoju produktivnu debljinu i kvalitet.

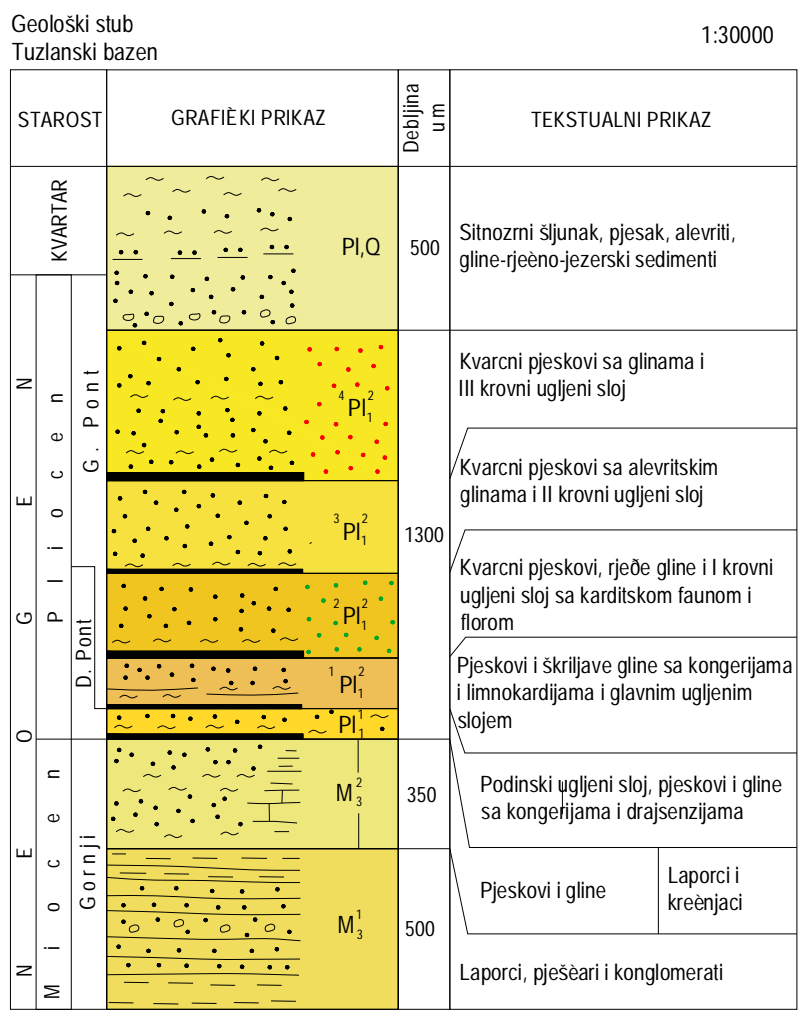

SI. 2. Geološki - stratigrafski stub krekanskog sinklinorijuma 


\section{ANALIZA STANJA NAPONA OKO PODZEMNE PROSTORIJE U UGLJENOM SLOJU METODOM KONAČNIH ELEMENATA}

\section{Programski paket ADINA}

ADINA (Automatsko Dinamičko Dodatna Nelinearna Analiza), je komercijalni programski paket za analizu metodom konačnih elemenata, koji, obzirom da je pogodan za analizu napona u čvrstim stijenama (2D i 3D model), te različitih struktura, ima široku primjenu $u$ industriji $i$ akademskoj zajednici. U radu je korištena verzija 8.6. kojom je pokazana razlika u preraspodjeli napona između nepodgrađene prostorije i prostorije podgrađene ankerima, odnosno prikazano je sekundarno i tercijarno naponsko stanje u svodu prostorije nastalo ugradnjom ankera. (1)

\section{Ulazni parametri radne sredine}

U ulazne parametre radne sredine spadaju geomehaničke karakteristike radne sredine, litološka građa u zoni analiziranog slučaja, geometrija podzemne prostorije nepodgrađene i podgrađene ankerima.

Tabela 1. Geomehaničke karakteristike

\begin{tabular}{|l|l|l|l|l|}
\hline \multicolumn{1}{|c|}{$\begin{array}{c}\text { KROVINA } \\
\text { GLINE }\end{array}$} & \multicolumn{1}{c|}{$\begin{array}{c}\text { UGLJENI } \\
\text { SLOJ I }\end{array}$} & $\begin{array}{c}\text { UGLJENI } \\
\text { SLOJ II }\end{array}$ & $\begin{array}{c}\text { UGLJENI } \\
\text { SLOJ III }\end{array}$ & \multicolumn{1}{c|}{$\begin{array}{c}\text { PODINA } \\
\text { PJESKA }\end{array}$} \\
\hline$\gamma=21 \mathrm{kN} / \mathrm{m}^{3}$ & $\gamma=12 \mathrm{kN} / \mathrm{m}^{3}$ & $\gamma=12 \mathrm{kN} / \mathrm{m}^{3}$ & $\gamma=13 \mathrm{kN} / \mathrm{m}^{3}$ & $\gamma=1,70 \mathrm{kN} / \mathrm{m}^{3}$ \\
\hline$v=0,40$ & $v=0,21$ & $v=0,22$ & $v=0,22$ & $v=0,35$ \\
\hline $\mathrm{C}=0,07 \mathrm{MPa}$ & $\mathrm{C}=3,5 \mathrm{MPa}$ & $\mathrm{C}=3,2 \mathrm{MPa}$ & $\mathrm{C}=3,0 \mathrm{MPa}$ & $\mathrm{C}=30 \mathrm{MPa}$ \\
\hline$\varphi=22^{\circ}$ & $\varphi=30^{\circ}$ & $\varphi=30^{\circ}$ & $\varphi=30^{\circ}$ & $\varphi=35^{\circ}$ \\
\hline$\sigma_{\mathrm{z}}=0,02 \mathrm{MPa}$ & $\sigma_{\mathrm{z}}=1,4 \mathrm{MPa}$ & $\sigma_{\mathrm{z}}=1,3 \mathrm{MPa}$ & $\sigma_{\mathrm{z}}=1,20 \mathrm{MPa}$ & $\sigma_{\mathrm{z}}=0 \mathrm{MPa}$ \\
\hline $\mathrm{E}=25 \mathrm{MPa}$ & $\mathrm{E}=600 \mathrm{~Pa}$ & $\mathrm{E}=600 \mathrm{MPa}$ & $\mathrm{E}=600 \mathrm{MPa}$ & $\mathrm{E}=300 \mathrm{MPa}$ \\
\hline
\end{tabular}

Na slici 3. dat je strukturni profil ugljenog sloja sa položajem, vrstom i oblikom podzemne prostorije koja je predmet istraživanja i podgrađivanja. Takođe, date su i sve neophodne, a raspoložive, geomehaničke karakteristike ugljenog sloja i pratećih naslaga za revir „Marići“ za 16 sprat (GDVH). Ovi podaci se u radu koriste kao osnova za sva modeliranja. (2) 


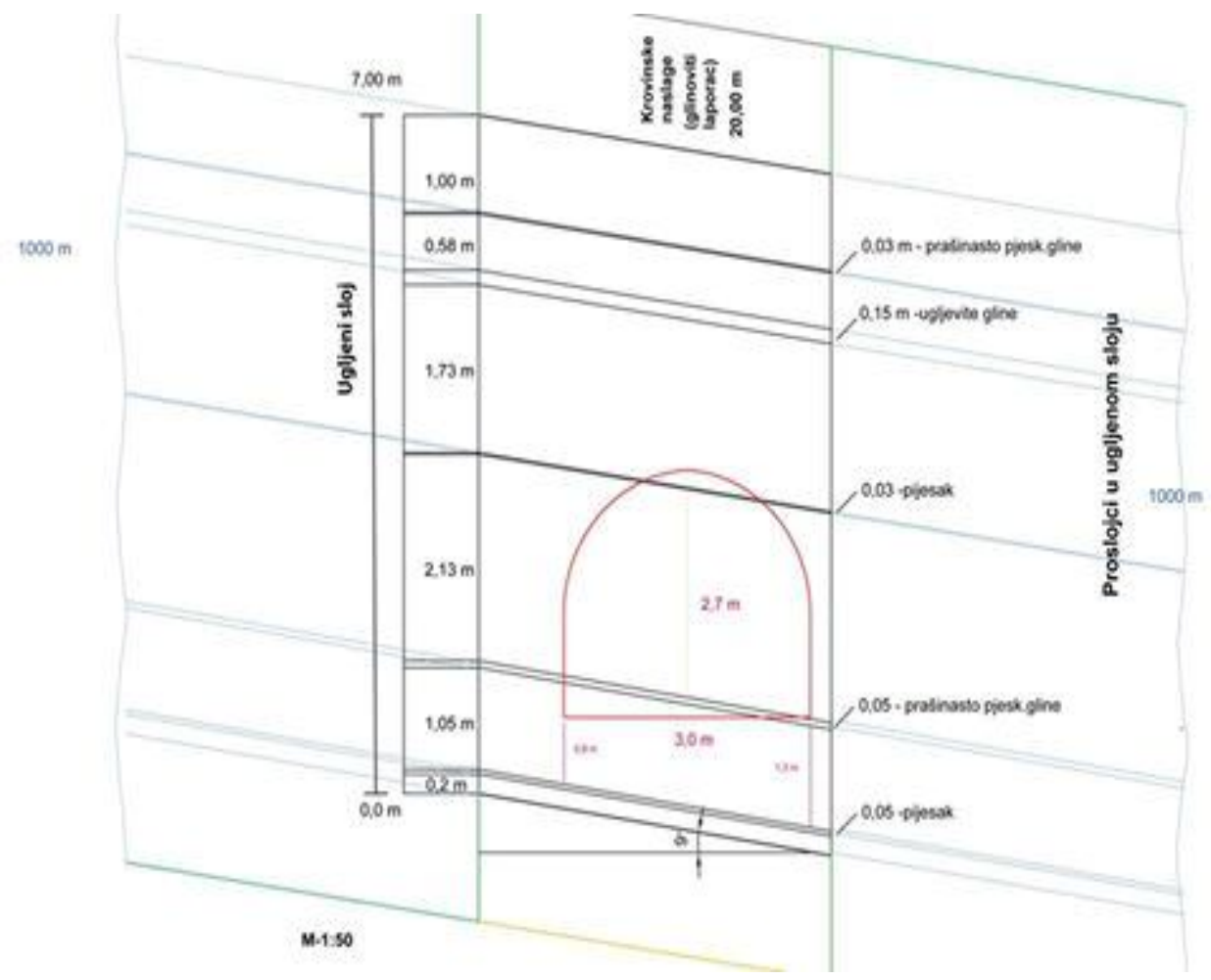

SI. 3. Strukturni profil za polukružni oblik prostorije za (GDVH- 16 sprat)

\section{SLUČAJ 1:}

Analiza je rađena u dva geološka slučaja, i to za podgrađivanje prostorije sa 3 ankera u prvom slučaju, i sa 5 ankera u drugom slučaju.

MKE model sa naznačenim rubnim uslovima i zadanim opterećenjem sa ugrađenih 3 ankera.
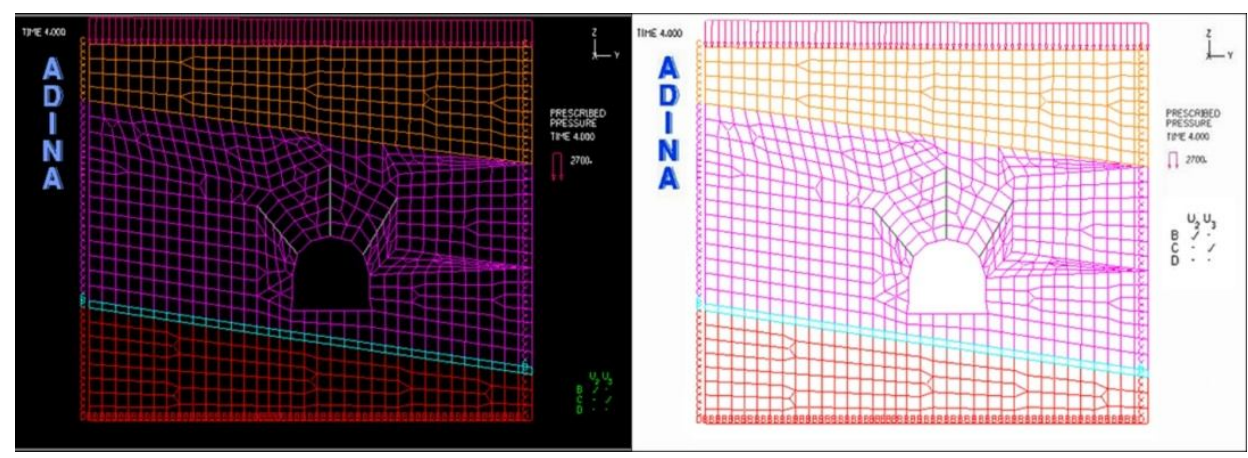


\section{SLUČAJ 2:}

MKE model sa naznačenim rubnim uslovima i zadanim opterećenjem sa ugra-

đenih 5 ankera.
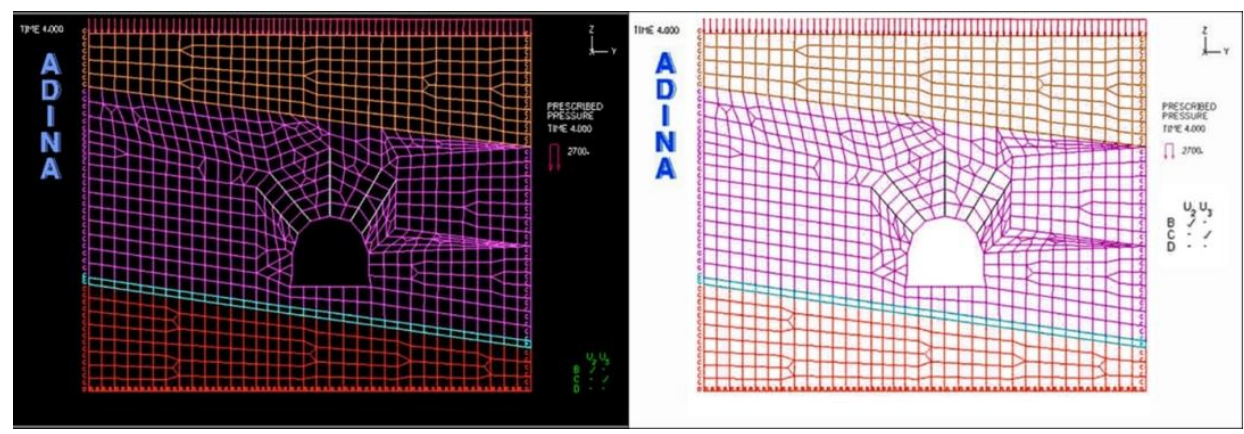

$\mathrm{Na}$ slici u prvom slučaju prikazan je model konačnih elemenata za prostoriju sa polukružnom svodom i ugrađenim ankerima, položajem litoloških članova i prikazom rubnih uslova. Model se sastoji od 3207 čvorova, sa pet grupa elemenata, a ankeri 14 generalisanih linijskih (truss) elementa. 2D elementi, koji predstavljaju ugalj, krovinu i materijal, sastoje se od 1044 kvadrilateralna elemenata sa 8 Gaussovih integracionih tačaka. U drugom slučaju model se sastoji od 3207 čvorova sa pet grupa elemenata a ankeri 24 generalisanih linijskih (truss) elementa, dok 2D elementi, koji predstavljaju ugalj, krovinu i materijal, od 1044 kvadrilaterala elementa sa 8 Gaussovih integracionih tačaka.

\section{Prikaz vertikalnog napona $\sigma z \mathbf{i}$ aksijalnih sila $u$ ankerima}

Stanje vertikalnih napona, odnosno raspon intervala od minimalne do maksimalne vrijednosti napona, dat je na slici i izražen je u $\mathrm{kN} / \mathrm{m}^{2}$. Negativan znak znači pritisak (-) dok pozitivan (+) zatezanje.

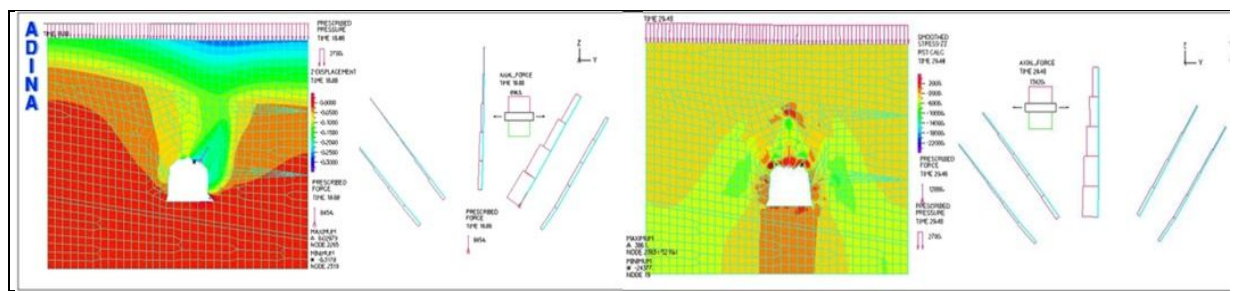

Sl. 4. Prikaz napona $\sigma z$ i aksijalnih sila u ankerima nakon iskopa profila sa 3 i 5 ankera

Prikaz vertikalnog napona oko prostorije ukazuje na pre raspodjelu napona u masivu. Sile u ankerima ukazuju da srednji anker ima manji intenzitet sile, dok bočni ankeri preuzimaju veća opterećenja a izražena nesimetrija je posljedica položaja slojeva.
Također, na slici je dat detalj prikaza aksijalnih sila koje djeluju na ankerima na kome se s gornje strane označava pritisak a sa donje zatezanje, dato u $\mathrm{kN}$. U slučaju 5 ankera, za razliku od slučaja kada je u prostoriji ugrađeno 3 ankera, može se uočiti 
da je intenzitet napona pritiska manji (po apsolutnoj vrijednosti), ali i da je intenzitet napona zatezanja nešto veći, i to u podinskom dijelu prostorije. Intenzitet sile $\mathrm{u}$ ankerima je također veći.

\section{Plastične deformacije, vertikalni pomak, plastični flag}

Veličine plastičnih deformacija su manjeg intenziteta oko prostorije sa ugrađenim ankerima. Plastične deformacije su naročito izražene u donjem desnom uglu prostorije, što je posljedica litološkog sastava i oblika prostorije (u podini je pijesak), te zato što oštri uglovi izazivaju visoke koncentracije napona. Plastične deformacije su izražene $u$ procentima (\%). Veličina plastičnih deformacija za prostoriju bez ankera je veća nego za prostoriju sa ankerima. Uočava se također da je intenzitet plastičnih deformacija, u ovom slučaju, manji sa 5, nego za slučaj iste prostorije sa ugrađena 3 ankera.

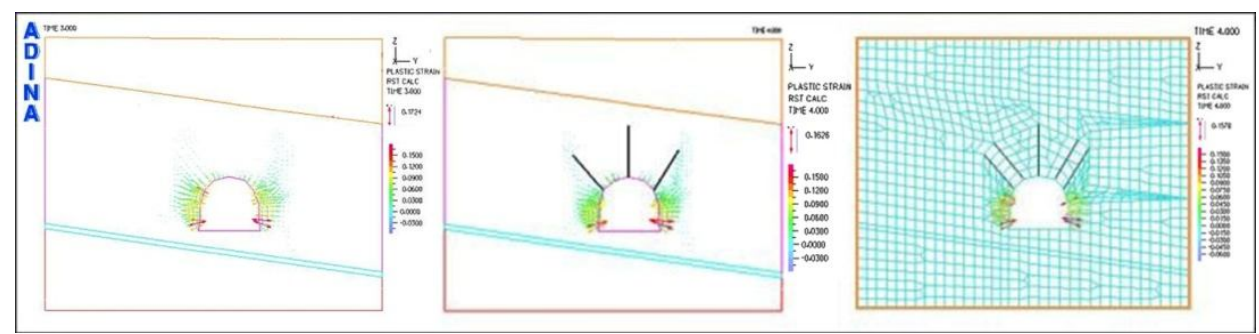

SI. 5. Uporedni prikaz plastičnih deformacija prije i nakon ugradnje 3 i 5 ankera

Vertikalni pomaci daju slikovit primjer kada je u pitanju primjena ankera, obzirom da ugradnja ankera u kratkom vremenu nakon izrade prostorije bitno utiče na smanjenje visine prostorije. Iz slike je jasno uočljivo da dolazi do promjene polja djelovanja iskopa na sekundarno naponsko stanje u masivu, i do promjena sekundarnog naponskog stanja u masivu nakon ugradnje ankera. Linije vertikalnog pomaka ukazuju da se bitno mijenja slika raspodjele vertikalnih pomaka sa ugrađenih 5 ankera. Upoređivanjem za iste uslove, ali za prostoriju sa samo 3 ugrađena ankera vidljivo je da intenzitet vertikalnih pomaka manji.

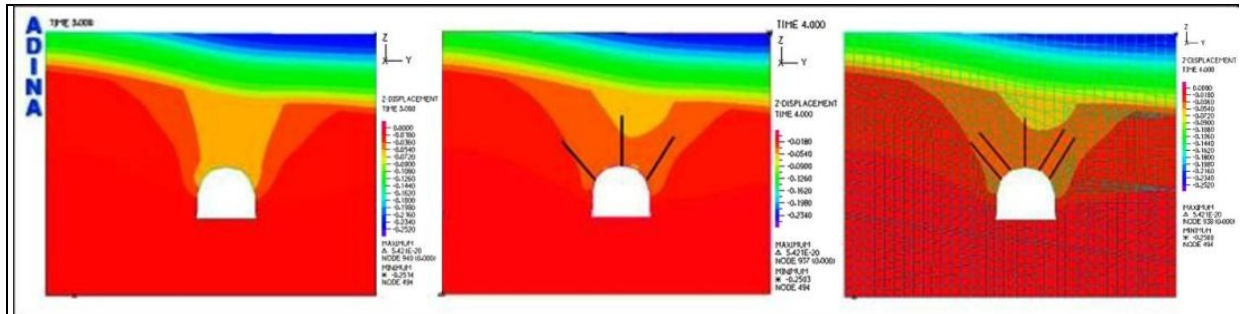

Sl. 6. Uporedni prikaz vertikalnih pomaka prije i nakon ugradnje 3 i 5 ankera

Plastični flag je pokazatelj nastanka plastične deformacije u Gaussovim tačkama elemenata, te ukazuje na zone, elemente elemente, koji su pretrpjeli plastičnu deformaciju. Iz legende je uočljivo da je plastifikacija nastupila kao posljedica preko- 
račenja Mohr-Coulombovog uslova loma. Ova je zona znatno izraženija bez ankera. Nije uočena plastifikacija za ostale uslove i kriterije (čvrstoće na pritisak, zatezanje).

Također, u legendi dato je objašnjenje na koje modele može i mora biti iz- ražena plastična deformacija zbog zatezanja, plastična deformacija zbog pritiska ili prekoračenja Mohr - Coulombovog uslova loma, a prikazano je da postoji evidentna razlika između slučaja sa 3 i 5 ankera.

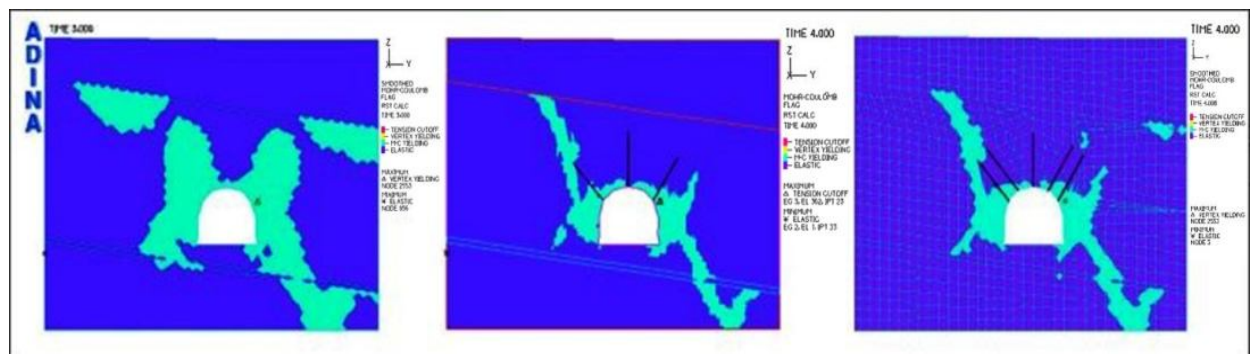

Sl. 7.Uporedni prikaz plastičnog flaga u vremenu prije u nakon ugradnje 3 i 5 ankera

\section{Sila čupanja ankera}

$\mathrm{Na}$ istom modelu, samo iz različitih pozicija ugrađenih ankera u strop vertikalno, ili pod uglom, razmatranisu i dati rezultati sile čupanja ankera. U rezultatima se obrađuju vertikalni pomak i prikazuje intezitet sila. Modelirana je sila čupanja, prvo koso postavljenog ankera, a zatim i sila čupanja ankera direktno iz stropa. Veličine sila i pomaka su prezentirane i date na adekvatnim crtežima, a to što je evidentno jeste da je veća sila čupanja kod ankera ugrađenog direktno u strop.

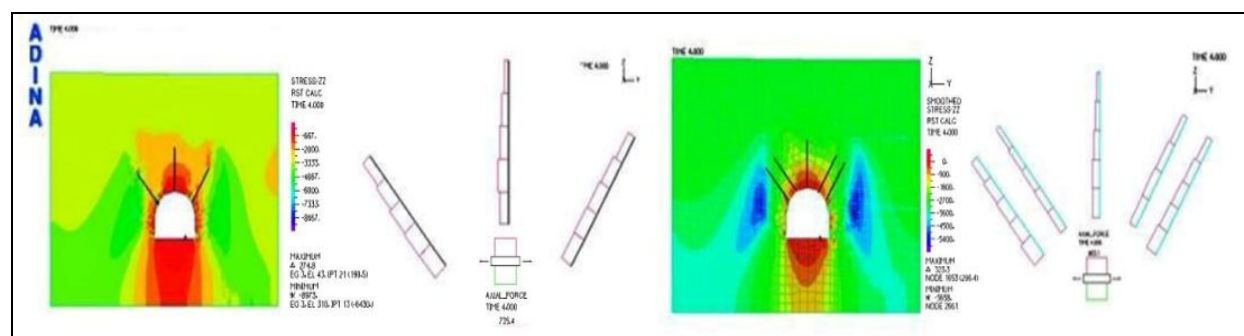

SI. 8. Sila čupanja ankera iz stropa prostorije

\section{ZAKLJUČNA RAZMATRANJA}

Na osnovu dobijenih rezultata može se zaključiti da u Rudniku lignita Mramor, na analiziranom profilu polukružnog svoda prostorije na 16-om spratu (TOH-16), postoji evidentna razlika $\mathrm{u}$ preraspodjeli napona kod podgrađivanja sa tri ankera i podgrađivanja sa pet ankera. Obzirom da je analiza stanja napona oko podzemnih prostorija u slojevitim ležištima sigurna metoda za izbor podgrađivanja podzemnih prostorija ankerima, numeričkim metodama izvedena je naponska analiza koristeći licencirani softver na RGGF-u Tuzla ADINA, verzija 8.6., s ciljem dobijanja što objek- 
tivnijih analiza i proračuna. Model ADINA, $\mathrm{u}$ inženjerskom smislu, daje pouzdane rezultate, u skladu s kojima se dobija pouzdana slika napona i sila u ankerima. Kroz softversku analizu napona dokazana je teza o preraspodjeli napona za sekundarno i tercijarno naponsko stanje u svodu i bokovima prostorije ugradnjom ankera, a što dokazuju dobijeni rezultati.

Dobijena sila čupanja iz modelirane vrijednosti mora biti bitno manja od sile praktičnog čupanja sa pumpom, iz razloga što se kod praktičnog čupanja stvara oslonac koji prave oslonac pumpe i privremeno ugrađena podgrada, te se time dobija veća vrijednost sile čupanja od modelirane vrijednosti.

\section{LITERATURA}

[1] ADINA, R\&D, Inc., Teory and Modeling Guide, Volume I: ADINA, Watertown, USA, 2000.;

[2] Filipović Z., Elaborat o klasifikaciji, kategorizaciji i proračunu rezervi uglja glavnog i podinskog sloja do kote +50 m, na području Mramor - Sjeverni krekanski sinklinorij sa stanjem, 2001.

[3] Fejzić, S., Naponska analiza podgrađivanja podzemnih prostorija u slojevitim ležištima ankerisanjem, Doktor- ska disertacija, Rudarsko fakultet Prijedor, Univerzitet u Banjoj Luci, Prijedor, 2014.;

[4] Gutić, K., Avdić M., Fejzić, S., Muratović, M., Omega anker u sistemu kombinovanog podgrađivanja, Drugi internacionalni naučni skup GTZ Tuzla 2012, Tuzla, 2012.;

[5] Osmić, M., Gutić, K., Mandžić, K., Brkić, J., Fazlić, E., Fejzić, S., Primjena ankera u rješenju prolaza širokog čela kroz prostorije izrađene na otkopnoj fronti, Univerzitet u Tuzli, RGGF Tuzla, Zbornik radova RGGF Tuzla, broj XXXVI., Tuzla, 2012.;

[6] Rudnik "Kreka" u Tuzli, Dopunski rudarski projekat, Otvaranje i pripreme I horizonta revira "Marići" jame glavni sloj rudnika "Mramor" u Mramoru, Dokumentacija rudnika Kreka, Tuzla, 2004.;

[7] Rudnici "Kreka"u Tuzli, d.o.o, Rudnik "Mramor" u Mramoru, Dopunski rudarski projekat, Otkopavanje 60m'KMŠC II i ostalih pojaseva revira "Mramor" jame Glavni sloj, Rudnika "Mramor" u Mramoru sa produženjem do 15 metara u slijepom dijelu, demontažom, preseljenjem i montažom, Dokumentacija rudnika Mramor, Mramor, 2009. 